\title{
Political dimension of European constitutionalism
}

\author{
Patricia Kaplánová ${ }^{1}$ \\ Uroš Pinterič ${ }^{2}$
}

\begin{abstract}
Author in the article tries to analyse different elements of document called European Constitution. Analysis is supported with theoretical framework of federalism, presented by Brezovšek. Authors is playing with idea of (con)federal and international organization elements of European Constitution and their mix. They are also trying to set some connections between so called common European identity as necessary condition to give legitimacy to the European Constitution. This became important question after "votes of non-confidence" to the European Constitution in France, despite it should be addressed already before. However, European Constitution is important document on the path of European integration and lack of support to it will slow down this process of widening and deepening European ties.
\end{abstract}

Key words: European Constitution, European Identity, Federalism, European Union, International Organization.

Autori sa v predkladanom článku snažia analyzovat' rôzne elementy dokumenty nazývaného Európska Ústava a to aj $v$ kontexte teoretického konceptu federalizmu od Brezovšeka. Autori sa „pohrávajú“ s myšlienkou (kon) federálnych a medzinárodných čŕt Európskej Ústavnosti. Zároveň sa snažia o vytvorenie prepojenie medzi tzv. Európsky identitami a legitimitou Európskej ústavnosti. Daná otázka sa stala vel'mi dôležitou po "hlasovaní o nedôvere" vo Francúzsku, aj ked" to bolo potrebné už riešit' skôr. Avšak samotný článok, ako aj autori zdôrazňujú, že Európska Ústava je dôležitým dokumentom na ceste k európskej integrácii a nedostatok podpory bude len spomal'ovat' proces rozširovania a prehlbovania väzieb medzi európskymi krajinami.

Klúčové slová: Európska Ústava, Európska Identita, Federalizmus, Európska Únia, Medzinárodná organizácia

1 Address: Mgr. Patrícia Kaplánová, Department of Political Sciences and European Studies, Faculty of Social Sciences, University of Ss. Cyril and Methodius in Trnava, Bučianska 4/A, 91701 Trnava, Slovakia. email: pata.kaplanova@gmail.com

2 Address: Doc. Uroš Pinterič, PhD., . Department of Public Policy and Public Administration, Faculty of Social Sciences, University of Ss. Cyril and Methodius in Trnava, Bučianska 4/A, 91701 Trnava, Slovakia. email: uros.pinteric@ucm.sk 


\section{Introduction}

In this article, authors try to systematically analyse European political system and its maybe-will-be constitution from federalist point of view. European history seems to be strongly marked with different federal models. In last decades Yugoslavia was one of the most evident case because it showed destructive potential of federalism. Authors ask themselves what is the right federalist approach that enables (con)federal states such as United States or Canada to stay unchanged for relatively long time. They also wonder what European Constitution in federalist sense means for further development of European Union. Yugoslav experience showed that rigidity of federal system with great cultural differences is not able to survive on the long run. On the other hand American federation seems to be strong enough that survived over two hundred years long period despite American society is one of the most heterogeneous. In the first part of this article, authors define some basic characteristics of federalism and its implications on political system. In second part of the article, there is analysed constitutional definition of federative element in the European Union. Third part tries to set some of the main social elements in context of federative constitutional elements in analysed political systems.

\section{Some theoretical assumptions of federalism}

Creation of the European Union with the Maastricht treaty in 1992 and draft of the so called European Constitution in 2003 gave us third great (con)federal political system in western civilisation after United States (US) and Canada. However many differences exist among these three political entities already on declarative level, not even mentioning real situation. This article will only deal with basic elements of entity mentioned before: its balance of governance organization on different levels, meaning (con)federalism.

Despite it is not new; we have to define what we understand under basic terms, such as federalism, federation, and confederation. Those definitions will be also our measure for analysing federal elements in European Union constitution ${ }^{3}$. Brezovšek (1994, p. 35 ) stresses that when defining federalism one should be aware of difference among important and unintended characteristics of concept itself, one should try to explain and not only to define concept and most of all, it is necessary to understand concept as pour category and not only as description of situation.

In short federalism is, according to different authors, method of sharing not only power between branches of power in a single country but also sovereignty between

3 According to EU constitution we have to be aware that some changes can be still possible 
federal and state level. Principle of (con)federalism is defined in constitutional act as agreement establishing both levels of government as well as their spheres of the authority.

In this context Brezovšek (1994, pp. 37 - 40) finds broader and narrower definition. In a broader sense, federalism is understood as integration of people and institutions on basis of all involved consent and following special aims without scarifying their own individual identity (Brezovšek, 1994, p. 37, p. 45). On the other hand, narrow definition deals only with system of ,good" government, where main question is how to organize government to block different anomalies as it was the case of legitimately elected Nazis' government that caused the Second World War.

In (con)federations, legal sovereignty is shared among federal (national) government and constituent states or provinces and neither level can abolish another. Each level has constitutionally defined its specific functions. Federal level usually keeps so called statecreating functions as foreign affairs, defense, currency and national public finances, while provincial level gets so called state-maintaining functions (e.g.: education, law enforcement, interior, local government, social security, etc.) It is also common that in all (con)federative political systems, states have guaranteed control in national policy-making through an upper chamber of the assembly. Brezovšek (1994, p. 23) argues that federal political system has two levels of government, each with its own powers and constitutional rights, formal division of legislative and executive power and separated budget revenues. Federal system has also common written constitutional act that defines jurisdiction of both levels and it is not possible to change it without permission of both levels, Supreme Court that decides on disputes between federal and provincial level of government and explain constitutional provisions. Federal system also includes institutions and processes that enable cooperation among both levels of government. Last important characteristic is the existence of federal institutions such as bicameral parliament, where special interests of minorities and federal units are defined and protected (Brezovšek, 1994, p. 23).

One of basic ideas of federalism is also coexistence of different communities and double loyalty, where for some ideas relevant context is federal state and for others federal unit and neither one nor other level of government has supremacy over another (Brezovšek, 1994, p. 55).

Federation is any political system that implements idea on shared sovereignty in context of national state into practice. However, in this article federation is understood as a political system with shared sovereignty where national level controls more policy fields. On the other hand, confederation is political system where national level is only some kind of coordination body for very narrow circle of different political fields and with broad empowerment of provincial governments. Just like anywhere there are no ideal types of federations and confederations. Accordingly, so called asymmetric 
federalism can be found in cases where one of provinces has more or less freedom than others.

All forms of (con)federalism can be either dual or cooperative. In dual federal political systems national and state government act independently and autonomously in their own spheres, linked only through the constitutional compact (Hague\& Harrop, 2004, p. 231). In this manner national government is required to maintain only activities that are especially allocated to it. Second form is cooperative federalism, where national government and states work together for common interest of whole. In this case national level usually offers leadership and leaves implementation to the lower level. Such federal model includes principles of solidarity and subsidiarity in contrast of contractual model of dual federalism. In this sense we can also understand cultural roots of both models. Dual federalism is strongly connected with idea of independent individuals who act together because of their (strategic) interests, while cooperative federalism stresses interdependence of individuals who act together because they feel much stronger as community working together and not only coordinating their separated actions. According to this, dual federalism can be defined as division of work while cooperative federalism can be understood as coordination of phases.

According to these characteristic Brezovšek (1994, p. 25) defines two approaches; European and American where first can be synonymous with cooperative federalism while last one can be understood as dual federalism. Further Brezovšek (1994, p. 37) argues that European conception of federalism support autonomy of federal units, while American model stresses importance of central issues.

According to Brezovšek (1994, p. 13), modern federalism is a product of national state with obvious regional or historical differences among different segments of a single nation. Such approach was understood as model of approaching ideal of modern political community. This federal model opposed to the unitary state as well as to the confederal model. The main propose is creation of one and unified state without elements of confederalism or independence of federal units (Brezovšek, 1994, p. 13). On the other hand Brezovšek (1994, p. 43) stresses that federalism is far from being the best solution in case of all political systems, what was quite obvious in case of former Yugoslavia. One can even say that rigid federative system in combination great cultural diversity of federal units was one of most important disintegrative factors, next to the economic situation.

Brezovšek (1994, p. 43) argues that federalism should be interpreted in context of historical, social and political situation in political system.

There are many different approaches to the exploration of federalism in different political system but main characteristic are following: written constitution where federal relations and conditions of division of powers are defined, definition of competences of each level of government and statement that one-sided change of those competences 
cannot be changed, definition of institutional framework on each level, defined regular contacts with people on each level, etc.

According to this different authors use so called multifactor approach following factors are important for situation in federation and its units:

- Historical-cultural dimension, where expression of identity is important; especially in federations with many different cultures or languages.

- Political-constitutional dimension; where possibilities of federal units to define, organize and control their own political structure and its relation to the federal level and local political institutions together with maintaining balance between different levels.

- Fiscal dimension, defining the level and possibility that federal units set and collect taxes on their own as well as defining level of central (federal) power to redistribute collected money among federal units.

- Program dimension, defining functional policy areas where federal units have their exclusive or main power. Also important is role of federal units in those policy fields that are basically part of federation competences.

- Representing/cooperation of federal units at federal level, set possibility of federal units to be represented directly on federal level via upper chamber of bicameral parliament with influence on matters concerning relations between both levels of government. On the other hand this representative role can be limited only on executives of federal units cooperating in policy-making process (this role is much less formalized).

- Role of federal units in supervising of local government where jurisdiction of federal units over defining shape, functions and financing of local governments is set as well as role in officers employment and autonomy of local level form federal unit interference (see Brezovšek, 1994, pp. 56-58).

\section{Constitution of European Union and (con)federal elements}

In our perspective the so called European Constitution is most problematic because of sole nature of the European Union. In the beginning European Union was system of three international organizations established after the Second World War based on federalist idea of the founding fathers that was not applicable in that time. However three communities developed into more and more interconnected system expanding over time period of thirty years. Development achieved spill over effect from communities to the European Union with Maastricht Treaty in 1992. From that point on, we can understand European Union as more than just international organization (despite some elements of state, such as European Parliament, were present also in previous period). Weiler (1999, pp. 130-138) defines so called mixed agreements that defined European 
Union as something between international organization and federation and argues that the European Union is ,sui generis association of sovereign states, which could in a sense be seen as a sign of agnosticism“ (Weiler, 1999, p. 131). In July 2003 (decade later form the European Union establishment) Treaty on European Constitution was drafted and accepted by the European Convention. This can be understood as another important step in development of the European Union from international organization to the state based political system. At the same time European Union system spread from six founding states to 25 member states in year 2004 and to 28 in 2013. This conceptual - policy development and more than four time growth of member states caused also development of procedures and institutions. Relations inside the European Union member states are because this specific development are far from stable and many argues that the European Union works only because nobody strictly respects set rules. This was more than obvious in attempt to accept the so called European Union Constitution that was turned down on referenda by France and Netherlands. After first fiasco of federalization of the European Union new attempt to provide up-dated European institutional framework called Treaty of Lisbon was carried out. European Union member states learned their lesson in previous attempt and almost all of the states decided to accept Treaty of Lisbon in comfort majority in legislatures. Only Ireland has great democratic instrument build in their own national constitution that demands every amendment of national constitution (what Treaty of Lisbon is) to be confirmed on general referenda. On June 12th 2008, democracy prevailed over technocratic implementation of important changes for the European societies. ${ }^{4}$. For the representatives of the European Union (including majority of national political elites in member states) this, in fact, minority block of EU institutional and political reforms was act of irresponsible behaviour that should be avoided and it also caused panic at least for the limited period of time. These pro-federal European elites openly criticized one of tools of democracy. After few days when they realized their orientation they changed their discourse again towards reunification of political powers to achieve „united Europe". French and Dutch achieved that there was no European Constitution (by negative result of referenda on this subject) and Ireland blocked it, at least for the limited period of time. Another European institutional reform (that certainly is necessary even today) in the form of Treaty of Lisbon took place.

We can indicate different reasons for such behaviour that has legitimate foundation in democracy, lack of common European identity and political motivation of the nations. It seems that there is no strong feeling of attachment to the European Union among so called European citizens (Pinterič, 2004, pp. 70-75).

4 We can hardly find any exact argument that there is single European society that could be compared to the American society. Even nations in former Yugoslavia had more in common (next to the cultural diversity) than European nations. 
According to our article we will try to analyse (con)federal relations among the member states on the basis of the European Constitution. If in the cases of the USA and Canada relations among federal and state/provincial level are more or less clear in the case of the European Union is far from being so. In this system we can find elements of international organization, confederation and federation.

Elements of international organization can be seen in parts where Constitution is still referring to the European Communities and is obvious in cases, such as Protocol changing the Euroatom Treaty (Evropska konvencija, 2003, pp. 263-267). Even more important is part of the European Constitution, dealing with membership in the European Union (Part I, Title IX, Article 57-59) where states that special conditions for membership must be fulfilled as well as for the leaving the union. However, ability for free entrance and exit are far from being characteristic of (con)federal state.

At the same time, many other articles of the Constitution (re)affirming different European institutions and political procedures and policies lead us to assumptions that European Union is much more than international organization. We can define political institutions on two levels, despite European level is not absolutely typical and empowerments are not completely comparable to the political systems of US or Canada. Also legislative procedure (again atypical) is defined as well as special policies reserved for European level, where national states have only right to implement them.

Let us follow list of characteristics of (con)federal states according to Brezovšek (1994, p. 56-58).

Historical - cultural dimension in the European Constitution can be understand as mix of federal and confederal approach with double citizenship (Part I, Title II, Article 8 ) and absolute respect of cultural diversity of member states nations (e.g. Preamble of Part II of European Constitution). However, with strong respect of member states history, culture, language and traditions in this aspect European Constitution seems to be supporter of confederative order. More precisely we can argue that such situation is a consequence of political compromise accepted by European Convention as any and every other article. In this sense Constitutional document of European Union must be understood as political compromise based on concrete historical and international situation in certain period.

Political - constitutional dimension of European (con)federalism is in sole constitution and other constitutional documents (Treaty of Maastricht, Amsterdam, and now also Lisbon). It is possible to understand them as documents defining European Union (con)federal state in relation to international organization and from content point of view as document trying to organize European Union as federal state with written constitution and precisely defined characteristics and competences of each part. This dimension cannot be separated and analysed independently from historical-cultural 
one $^{5}$. Most simplified explanation is that any constitution (and especially federal one) is painting of concrete political and historical situation in state(s) defining constitution. This is also an answer to such mix of different elements of international organization, federal and confederal political system in case of European Constitution. This mixed elements were initially present long before the European Convention started its work (see Weiler, 1999, pp. 130-136) Member states are, with European constitution as it is, trying to get the best parts of each system. However there are some important questions learned from Yugoslav situation that are not examined in details and that can cause selfdestruction of European Union, especially if this, international con-federal organization mix" get into another crisis as it was in case of splitting on two blocks pro and contra American invasion on Iraq. According to security questions Treaty of Lisbon made step back to confederalism or even better to the sovereignty of nation states, claiming that national security is exclusive competence of member states (Article 1, paragraph 5 of Treaty of Lisbon). It shows that European Union is not able and willing to provide common security framework despite there were strong tendencies towards common European security and foreign policy.

Fiscal dimension can be called controversial one. On one hand, there is independent European budget with free redistribution of finances that can be understood as federal element. On the other hand, most of money to the European budget is paid by member states from their budgets and only small amount of money directly as percent member states VATs. This fiscal dependence of European level and free budgetary policy of member states can be understood as confederal element (for basic fiscal framework see European Constitution Part I, Title VII and Part III, Title VI, Chapter II).

Program dimension seems to be most important or even crucial in case of the European Union. In decades of European Union development more and more policy issues were decided on European level on majority principle that disables member states to block decisions with opposing the solution. European Constitution as ,federal“" European matter defines following policy issues:

European Union has solely power to define competition rules necessary for functioning of internal market on areas of monetary policy of member states of Euro aera, for common trade policy, custom union and in the field of sea biological sources in framework of common fishing policy. European union has also solely power to ratify international agreement if this there is such provision in legal act of European Union, if such agreement influences enforcement of EU power or if such agreement influences on legal acts of the EU (EC, part I, Title III, Article 12). Constitution of the European Union provides also Quite influential role of European Union in fields of internal market, freedom, security and rights, agricultural policy, transport and pan

5 Or at least cannot be understood properly without taking historical-cultural dimension into account. 
European networking, energetic, social policy in context of third part of European constitution, economic, social and territorial cohesion, environment, consumers protection and common security of public health (European Constitution Part I, Title III, Article 13). In the same article many competences are also reserved in the field of research, technology and space as well as in the field of development and humanitarian aid. In Part I, Title III great competences are also reserved for the European Union in the field of common foreign and security policy. With flexibility clause possibilities are open for further federalization of the European Union. In this sense we can argue that in filed of policy issues strong tendencies toward federal order are present.

Representing/cooperation of federal units at federal level in case of the European Union exist in many institutional ways but simultaneously this representation is more or less blocked. In case of the European parliament nationally elected parliamentarians are joined in so called European parties on basis of political believes and not nationality, and it is hard to coordinate solution on base of national interests when there is more than 600 parliamentarians and no national group has more than 100 parliamentarians. Same situation is in the European Commission which is strictly defined as an organ that protects so called European interests. Council of the European Union seems to be only organ of the national interest protection, but also its role is more and more limited with majority decision process in more and more issues.

Role of supervising local governments seems to be the most protected from European Union interference. Not matter if we as local understand national or local level, European union has no additional power to control policies in much larger extend than it is necessary for protecting common European interests. In this context, most important means of control and sanctioning seems to be temporary exclusion from rights and benefits rising from membership (EC, Part I. Title IX, Article 57) as well as financial sanctions defined in section on common economic policy (EC, Part III, Title III, Article III-76) as one can also expect according to nature of the European Union.

According to defined factors we can argue that European Union is political system that is more than international organization, less than state and more federal than confederal, at least in its draft version of constitution. In practice? one can see confederal background especially in the area of cultural dimension and also in control of federal level over national or local level, while in all other dimensions (fiscal, program, constitutional and also representative) stronger federalist ideas are present. We can argue that European Union is sui generis subject that has strong political pretensions to become federal state. Six years later we can also relativize Weilers' argumentation on mixed agreements cited above. European Constitution, despite still not ratified is the document clearly showing that the European Union wants to function as federal state and not only as mix of international organization possibilities and federal wishes. However, there seem to be strong historical and cultural conditions opposing them. 
Short notice on those „obstacles“ will be subject of following part of this article.

\section{Social conditions of (con)federalism}

Some doubts about future of European Union were more or less successfully solved in European Constitution. Among most problematic were definitely those dealing with possibility of leaving the Union and (con)federative order (see Pinteric, 2002, pp. 7579). However, Treaty of Lisbon is clearly introducing all the possibilities for leaving the European Union and also possibilities to re-enter the European Union.

With special provisions on possibility to step out of the European Union European constitution in this part seems to follow more international organization framework, which is more reasonable for all cases where member state finds more costs than benefits of being member. On common level European Constitution promote more federal framework than it was set by previous Treaties. However, there is also possibility for every state to become member of inner circle of member states who cooperates even strongly in some policy area. We can argue that European Union is becoming federal state with safety fuse in shape of possibility to leave the Union. Last element can be understood as some kind of protection from another violent end of another federal political system on European continent.

Brezovšek (1994: 49) as a special and most important accelerator consolidation of federal political system understand the development of so called federal spirit or common identity. Integration of federal units is in positive linear connection with development and strength of common identity. Only other form are different shapes of absolutism or force that necessary brings dissatisfaction and opposition to the federalist ideas. From this point of view most problematic seems to be integration of different ethnic communities in broader political unions (see Brezovšek, 1994, p. 49).

\section{The debate on future development of European constitutionalism}

In the meantime the socio-economic situation in the European Union changed significantly and re-opened questions of the further development of the European Union. One should notice that the ,deepening and widening“ period of the European Union took place during relatively positive economic situation. On the other hand the 2008 economic crisis is often compared to $1920 \mathrm{~s}^{6}$ economic crisis and thus tectonics changing in a sense of the economic relations. Under the influence of such economic instability one can uncover different layers of European values variations. So if the time of prosperity enables general agreement among European politicians on what is important for further development of the European Union. Economic crisis shows that under the pressure Europe is still the continent of nationalisms and differences. If the 
idea on European Union as a (con)federation was mainly supported (with exemption of Euro-sceptics), in 2015, after 7 years of economic crisis, picture is completely different. United Kingdom is planning the referenda on staying within the European Union. Despite they are considered to be always among Euro-sceptics and requesting bit different treatment, such idea shows strong determination to keep the sovereign rights of the state at any costs. On the other hand, even more interesting is Greek case where in initial period, whole Europe was trying to help Greece to stay within the European Monetary Union, while in late 2014 statements, expressing acceptance the possibility that Greece will leave European Monetary Union were not unusual any more. And on the other hand, with the change of the government in the Greece, the country showed again that European Union is less and less based on political principles of democracy, which are replaced by pure economic interest power-play. However, within this game, there is very fragile balance where Greece is still the European Union member state and at the same time it is a European country. First means that any serious sanctions against Greece, resulting in Greek bankruptcy will affect not only Greece (who has no room for adjustments) but also the whole European Union (who has even less legitimacy than before the economic crisis). On the other hand, Greece being European country is more ideological question that appeared in last days, when Greece was visiting Russia and the option of Russian support to Greece was exposed. Greek option to ask Russia for economic help might solve some short term economic issues of the Greece but would (within the current geo-political situation) meant ideological separation of Greece from so called „European values“. By not asking Russia for economic help, Greece placed itself once again in the position of European country, even if this means its further dependency on the demands of European Union and predominantly Germany. However, the seriousness of the situation concerning the lack of the European Union spirit is best illustrated with recent Greek demands towards Germany to pay second world war reparations, that belong to Greece based on the objective responsibility of Germany for the damage caused by Nazis regime during the second world war (this is actually unresolved issue also in Slovenia, but there is no political courage to open the question). On one hand, this demand is not only absurd but to the certain level infantile from the position how it was placed in the frame of economic dependency of Greece on the European financial support. At the same time, this demand is absolute proof of the nationalistic power within the Europe. Greek government, pushed in the corner between demands and expectations of poor citizens and international financial institutions was willing to open up one of most inappropriate ideological topics, which leads to the question of what the European Union really is.

We can agree to the certain degree that it is international organization facilitating economic cooperation and providing certain opportunities in the position where individual states act protective by economic logic. At the same time European Union 
can be considered authoritarian bureaucratic regime (not to call it directly Nazis organized corporation), which is failing systematically in the filed of understanding basic values upon which it should be build.

Set of different European policy measures strongly opposes idea that there is any economic freedom. Over-regulation goes to the level that at certain point in time, standardization of food products was brought to the level of shape and size of fruits and vegetables (including bananas), which were sold in stores (this measure was dismissed recently). However, it jeopardized local farmers and local grocery stores, which were trying to get local products when possible. Similar story is ban on classic bulbs (officially due to energy consumption), despite there is even health concern involving more recent illumination technology like LED lights. We do not argue that this is the case, but more likely than energy consumption, the main problem is connected to the expenses of „energy saving lights" which are from 4 to up to 70 times more expensive than classical light bulbs and thus economically unattractive to customers (not mentioning the quality of illumination). Similar story with health hazard regulations within the European Union is connected to car air-condition gas, where the European Union demands use of highly cancerogene and inflammable mixture R134yf instead of Ozone threatening gas R134a, used before. If one can understand the ecological concern of the European Union, it is much harder to perceive the position that it is ranked much higher than health risk for people.

Strange development paths, showing that the European Union is staying nothing more than economy facilitating system can be visible also in the question of development perspective policy. If the European Union was strong supporter of the sustainable development before the economic crisis of 2008, after this date, situation additionally changed (even before sustainable development was not correctly understood in whole, by the European policy measures) by simple forgetting of the concept and replacing it by energy efficiency as main guideline of next development perspective. In this manner one can freely argue that the European Union bureaucracy runs the European economy according to the interests of itself and other influential actors without any serious concern of consequences. Thus it blocks the competition at the free market, where people are not given a chance to vote for best solution by choice, since their choice is limited by the regulations, which define the acceptable solutions.

In the scope of democratic principles, recent development within the European Union shows the tendency towards centralized decision-making processes and increased control over citizens rights. The question of the democratic deficit was removed form the political agenda more or less systematically by providing some possibilities for civil society to participate in certain phases of the European policy processes. Ideally, solution is not too bad, but it shows that only limited number of people act on a international scale, while majority of citizens still prefer national or 
local level of participation, which is in many cases avoided by the fact that more and more of European legislation is directly included in the national legal systems. On the other hand this provide rather simple excuse for the national governments how to justify some policy measures which are questionable form the perspective of the basic principles of personal freedom and integrity. In this manner European Union follows the steps of the United States of America in the filed of surveillance and control over the citizens without any serious effect on their security. Last tragic reminder of this is in the case of aviation security where people are bothered at the security checks, while the cause of 150 deaths in French Alps inability to recognise obviously ill and mentally unstable pilot. If one analyses the list of causes of flight accidents the statistics will show that recently (in 2000s) only about $9 \%$ of all fatalities in air traffic are caused by terrorist acts, and about $55 \%$ by pilot error ( $34 \%$ direct pilot error, rest is related to the bad judgement of the plane or weather condition), while $22 \%$ by mechanical error and about $6 \%$ by weather. Long term analysis of 1015 plane accidents since 1950 until nowadays (2014) shows that one is historically more likely to die due to pilot mistake (53\%) mechanical failure (20\%), weather (12\%) than form terrorist act (8\%) (see Statistics, 2015). The shown numbers are quite steady over the time, which brings extra concerns in a sense that the quality of air planes did not significantly change over time as well as that the quality of pilots is doping over time, based on them as a cause of plane crash fatalities. Despite using the aviation accidents data, the same picture can be probably visible also in other spheres (just worse documented). The argument is, that the European Union strongly limits the freedoms of citizens and violates their personal integrity, while it does not provide any quality of life improvements for its citizens. In this manner one can argue that, if the European Union wants to see itself as state it will have to offer its citizens much more in the perspective of quality of life starting with decreasing the control and increasing the incentives for improvements of life quality. However, it can be argued that the main problem of the democratic deficit in the European Union is in fact ignorance, where unpleasant questions are seldom asked or marginalized, not only by the administrative and political structures but by media as well. Auto-censorship and lack of critical approach create too positive environment for misguided policies. Last such case was the proposition of president of the European Commission that European Union should develop its own system of the joined military units, which was mainly ignored despite people as well as the media should start with constant questioning of two basic principles. First, if he had nothing learned form the history and why he proposes the solution which leads to additional intensification of cold war mentality which is re-emerging after 2014, Ukrainian revolution (which is purely internal affair) and subsequent annexation of Crimea area to the Russian territories (which is international affair but not really direct concern of the European Union, still struggling with the economic crisis). Second question is, what is Junckner's 
plan to get the financial support for the project of the European Union army forces, since European economy in 2015 is far from sustainable and capable of such project with no value. At the same time almost one quarter of the total European population lives at the risk of poverty or social exclusion and even after social transfers, $16,7 \%$ is still threatened by the same situation (see Eurostat, 2014). Additional information on this topic is granted by the Standard Eurobarometer 82 where Europeans see as main issues of the European Union unemployment (45\%), economic situation (24\%), immigration $(18 \%)$, health and social security (16\%) while terrorism occupies last place among 13 issues with $6 \%$. At the same time about $50 \%$ of respondents tend not to trust the European Union while 37\% tend to trust the European union (see EB 82, 2014). From this perspective it can be clearly visible that the European political structures deal with macro-scale interests and clearly ignore human perspective in their ideas.

From the argument in this part of the article the question on what will happen to the European constitutionalism and (con)federalism is not really the most important one, since it seems that history provides necessary adjustments, showing the European Union the bitter reality. It is lack of any preparedness for acting as federal state due to the great differences among nations, which are changing according to different perspectives of individual member states on different issues. There is even hard to talk that something like European Union of different speeds, it is more European Union of different interests. With the threatening rhetorics the European Union will create good ground for lower synchronisation of these interests to the level that European Union will drop to the scenario of so called Europe a la cart, where individual countries will take what the are interested in and able to get, while not risking sovereignty in the fields where they believe that national policy supremacy is better option.

\section{Concluding remarks}

We can conclude that Document, called „European Constitution“ certainly has important (con)federal elements. These elements will strongly influence further development of the European Union as well as they will balance relations between national and European level.

One can indicate many federal elements in European Constitution which will impose transmission of sovereignty from national to the federal (European) level. However, there are many obstacles to such process. First one is cultural, connected with lack of so called common European identity, which is present among European citizens coming from 28 nation states only in small percent. Second obstacle is connected to the first one. It is top-down approach of enforcing European rules including European Constitution. In this manner we can be aware of possibility that there is necessary to strongly involve citizens from all member states if we do not want 
to risk that European Union become only mechanism in pursuit of national interests on expense of other states involved. One of most important elements of development strong (con)federal European Union is constant and in-depth informing of citizens about European Union and its advantages, to which most of European governments does not pay enough attention. All elements mentioned before become crucial in confirming European Constitution. It was clearly indicated in the case of France that there was lack of appropriate information on European Constitution as well and even more as lack of European identity which should prevail in deciding on European Constitution. In context of two „votes of no confidence“ to the European Constitution some euro-skeptics started rethinking scenarios of European disintegration. In order to prevent such situation, member states decided to by-pass the democratic will of nations in the case of the Treaty of Lisbon. Democracy was reduced only to Ireland that did its job well from the democratic point of view and slowed down or blocked EU institutional reform that could strongly influence member nations without their consent. However, we can argue that such situation will certainly slow down the whole process of European integration and can result in multi-layer Europe or in Europe of different speeds. However, current situation shows rather high level of discrepancies of the interests which lead towards long term so called European a la cart, where one selects what considers beneficial and avoids unnecessary obligations. Additional factor that will strongly influence the course of the European Union will be possible change of German chancellor Angela Merkel in the future, who recently „rules“ European Union by German economic supremacy in the economic crisis period and can thus dictate to certain extend the behaviour of other member states. This was especially visible when Sakrozy was French prime minister. After Merkel leaves her office, there is possibility that centralization tendencies in the European Union will be additionally weakened. Especially, if European administration does not find the solutions to real life problems and increases the trust of European citizens into the European Union.

\section{References}

BREZOVŠEK, M. (1994).: Federalizem in decentralizacija: Politološki vidiki položaja in vloge federalnih enot. Ljubljana: Karnatanija.

EB 82. (2014). available at : http://ec.europa.eu/public_opinion/archives/eb/eb82/eb82_fact si_en.pdf (3.3.2015).

EVROPSKA KONVENCIJA (2003): Osnutek pogodbe o ustavi za Evropo. Luksemburg: Urad za uradne publiukacije Evropskih skupnosti. (Draft of European Union Constitution)

EU. (2007). Treaty of Lisbon amending the Treaty on European Union and the Treaty establishing t he European Community, signed at Lisbon, 13 December 2007. Available at: http://bookshop.europa.eu/eubookshop/FileCache/PUBPDF/FXAC07306ENC/ FXAC07306ENC_002.pdf(20.4.2008). 
EUROSTAT.(2014).availableat:http://ec.europa.eu/eurostat/documents/2995521/6035076/304112014-BP-EN.pdf/62f94e70-e43a-471f-a466-2e84d102986 (3.3.2015).

HAGUE, R. - HARROP, M. (2004). Comparative government and politics: an introduction (sixth edition). Hampshire. New York: Palgrave Macmillan.

LISTER, FREDERICK K. (1996). The European Union, the United Nations and the Revival of Confederal Governance. Westport: Greenwood Press.

PINTERIČ, U. (2002). European Union - Relations between Member states and Applicant Countries. Central European Political Science Review: Vol.3 No.9/Fall 2002 (pp. 70-80).

PINTERIČ, U. (2004). National and Supranational Identity in the Context of European Integration. In A. Jankauskas et all: Central Europe beyond Double Enlargement. Vilnius: Lithuanian Political science association. (pp: $62-77$ ).

STATISTICS: http://www.planecrashinfo.com/cause.htm (7.3.2015).

WEILER, J. H.H. (1999). The constitution of Europe: „Do the new clothes have an emperor?“ and other essays on European integration. Cambridge, New York: Cambridge University Press.

Mgr. Patricia Kaplanova, is a PhD student of European studies at the Faculty of Social Sciences, University of Ss. Cyril and Methodius in Trnava. Her research interests include theories of democracy and democratization, global studies, European Union studies and Europeanization, political philosophy and political sociology.

Uroš Pinterič, PhD. is an associate professor of political science at the Faculty of Social Sciences, University of Ss. Cyril and Methodius in Trnava. His primary research interest is in regional development. However, he occasionally covers also the topics connected to the issues of modern democracy and human rights.

Mgr. Patrícia Kaplánová, Department of Political Sciences and European Studies,

Faculty of Social Sciences, University of Ss. Cyril and Methodius in Trnava, Bučianska 4/A, 91701 Trnava, Slovakia. email: pata.kaplanova@gmail.com

Doc. Uroš Pinterič, PhD., Department of Public Policy and Public Administration,

Faculty of Social Sciences, University of Ss. Cyril and Methodius in Trnava, Bučianska 4/A, 91701 Trnava, Slovakia. email: uros.pinteric@ucm.sk 